\title{
ASSESSMENT OF RECREATIONAL IMPACE ON BLACK BEAR HABITAT USE AND IMPLICATION OF GRIZZLY BEAR RANGE EXPANSION IN THE SOUTHERN TETONS
}

\author{
Steve Cain, Leslie Frattaroli $\downarrow$ GRAnd Teton National PARK \\ MOOSE WY

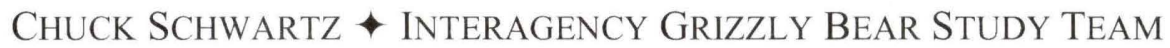 \\ MAMMOTH WY \\ DAVE MOODY WYOMING GAME AND FISH DEPARTMENT \\ LANDER WY
}

\begin{abstract}
$\uparrow \quad$ AbSTRACT
Grizzly bears have been moving slowly southward in the Tetons and increasing their abundance over the last 20 years. Their distribution is now expanding into areas previously occupied by black bears only that are heavily developed and receive proportionately more recreational use. At the same time, white pine blister rust and other humancaused factors may reduce bear food abundance in the near future. Grand Teton National Park is now positioned for an unprecedented interplay of bears, declining bear food sources, and humans in a relatively small temporal and spatial scale. In a new study designed to provide information critical to future black and grizzly bear conservation in this area, 6 spread spectrum technology (SST) GPS radio collars were deployed on black bears in the southern end of Grand Teton National Park in 2005. SST collars allow interrogation of the data in the GPS unit on a regular basis. GPS units were programmed to record positions every 90 to 190 minutes, and data were downloaded aerially on a weekly basis. Four female bears, two with cubs of the year, an adult male, and a subadult male provided the bulk of approximately 2700 positions obtained in 2005 , about
\end{abstract}

150 of which were visited for detailed site analysis. Sites visited were based on a randomly selected 24 hour period for each bear each week, and all sites were visited within a week of the location's recording. Efforts in 2006 will focus more intensively on site visits and associated data collection and analyses.

\section{$\downarrow$ INTRODUCTION}

Like most protected areas across the West, Grand Teton National Park (GTNP) has experienced the pressure of gradual but consistent increasing recreation use and development. This is particularly true in the south end of the park, where both front and backcountry use is intense, park development densities are highest, large blocks of Teton County private lands abut the park's borders and the town of Jackson is just a stone's throw away. With these increased pressures have come escalating black bearhuman conflicts, well illustrated by the 14 bears killed in Teton County by Wyoming authorities in the year 2002 alone. Furthermore, ecological changes, particularly the recolonization of wolves in the park, whitebark pine (Pinus albicaulis) blister rust 
infection, potential changes in ungulate numbers and distribution due to disease or related intensive management programs, and the slow but steady march of the Yellowstone grizzly population southward, also figure prominently on the landscape. The additive properties of these changes in GTNP have exacerbated the need for complex, potentially unprecedented human and wildlife management strategies. Scientific knowledge in several key areas of black bear habitat use, interactions with other species, and relationships with human activities will be critical in the development of these strategies.

Grizzly bears have been moving slowly southward in the Tetons and increasing their abundance over the last 20 years (Pyare et al. 2004, Schwartz et al. 2002). In addition, their distribution is slowly but surely expanding into southern areas previously occupied by black bears only that are heavily developed and receive proportionately more recreational use. At the same time, white pine blister rust and other human-caused factors may reduce bear food abundance in the near future. Thus, the Park is now experiencing an unprecedented interplay of bears, declining bear food sources, and humans in a relatively small temporal and spatial scale. The distribution of black and grizzly bears in GTNP, the associated infestation of blister rust, the complex ungulate management system, and a broad spectrum of human influences provide a compelling incentive to investigate the effects of changing food abundance on both resident grizzly and black bear populations, and the associated impacts on the bear-human interface. From a management perspective, black bear movement and habitat use data from the southern Tetons are essential for predicting, documenting, and mitigating changes in the bearhuman interface, both in terms of providing for longterm bear conservation and minimizing bear-human confrontations.

In an on-going study in the park's more remote northern half, GTNP and the Interagency Grizzly Bear Study Team (IGBST) are investigating relationships among recreation, grizzly and black bear habitat use, and the implications of potentially declining food sources. The northern study presents a unique opportunity to conduct this companion work in the southern end of the park on black bears, thus contrasting 1) high vs. low recreation use and development, and 2) grizzly- occupied vs. grizzlyfree effects on how black bears use the landscape and interact with humans. The results of both studies will help us predict how bear-bear and bear-human relationships may change as grizzlies colonize the southern Tetons. This will aid National Park Service,
U.S. Forest Service, state, county, and city managers in planning future recreation management appropriately, with long-term bear conservation as a primary component. Results of this study will also help land managers mitigate current effects of recreation on black bears and reduce human-bear conflicts.

As food resources become more limited, the competition between black and grizzly bears will amplify. Scenarios discussed above suggest an increase in bear-human confrontations as a result of declining foods and the potential influence of ungulate management practices. Accordingly, this study and the companion northern study will provide information on habitat use and foraging habits of these two overlapping bear populations, a more detailed understanding of how black bears use the ecosystem, how grizzly bears interface with black bears that share the landscape, how each of them interface with ungulate management programs and share the landscape with humans, and, finally, what changes might be expected as major bear foods decline and grizzly bears increase their use of the southern Tetons. This information is critical for providing a solid foundation to direct adaptive management policies for bears, ungulates, and human recreation within GRTE (Grand Teton National Park). This work, therefore, represents a compelling combination of research, management, and conservation interest.

\section{$\downarrow$ OBJECTIVES}

The overriding objectives of this study are to:

1) Evaluate black bear movements, activity patterns, and habitat use in response to patterns of visitor use and development, and use of whitebark pine and other foods and habitat resources.

2) Evaluate consequences of future interspecific competition between grizzly and black bears in the southern Tetons and the potential effects on humanbear conflicts.

\section{STUDY AREA}

This research is being conducted in the southern Greater Yellowstone Ecosystem, specifically within the southern half of GTNP (Fig. 1) where grizzly bears are absent or occur infrequently and at low density. GTNP is located in northwest Wyoming, just south of Yellowstone National Park. The Teton Range runs north to south approximately 40 miles and is bordered to the west by Idaho's Teton

*Appendixes are available upon request. Contact UW-NPS through our website www.uwyo.edu/uwnps 
Valley, to the east by Jackson Hole, to the north by Yellowstone National Park, and to the south by the Snake River mountain range. Seven glacial lakes and associated drainages lie east of the range, creating numerous riparian corridors. The study area will focus from Leigh Canyon to the southern border of the park. The area is surrounded by National Forest to the East and West. The southern border is lined with several housing subdivisions, a ski resort and the National Elk Refuge. The study area encompasses the valley floor, riparian corridors along the Snake River, alpine lakes, and the peaks of the Teton Range. The habitat is very diverse, ranging from valley sagebrush-grassland meadows to whitebark pine and subalpine fir stands.

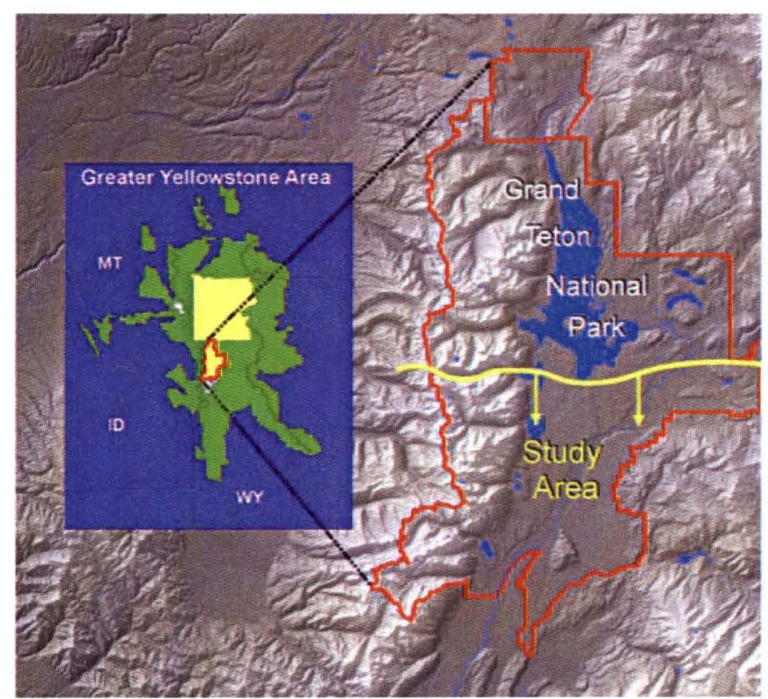

Fig. 1. Study area in Grand Teton National Park

\section{$\downarrow$ METHODS}

\section{Trapping and radio-collaring}

All trapping was conducted with culvert traps at low elevations on or near the valley floor, in areas away from human activity. In 2005, trapping began 20 May and ended on 29 September. Traps were baited with meat from elk, moose, or deer roadkills within the park, and were set at 6 different locations for a total of 219 trap nights (Table 1). Captured bears were fitted with two ear tags and a pit tag, a vestigial pre-molar was taken for aging, hair and blood samples were obtained, and several measurements were taken. Those bears meeting sex, age and weight requirements were fitted with Telonics spread spectrum technology (SST) downloadable GPS radio collars. This technology allows for interrogation of the collar to collect stored GPS fixes on a regular schedule. All bears were released on site.

\begin{tabular}{|l|l|l|}
\hline Site & $\begin{array}{l}\text { Total Trap } \\
\text { Nights }\end{array}$ & $\begin{array}{l}\text { Successful } \\
\text { Trap Nights }\end{array}$ \\
\hline Whitegrass & 26 & 0 \\
\hline Kaulfman JY & 75 & 8 \\
\hline Jenny Lake & 33 & 1 \\
\hline JY North & 35 & 3 \\
\hline Lupine Meadows & 26 & 0 \\
\hline Beaver Creek & 24 & 0 \\
\hline Totals & $\mathbf{2 1 9}$ & $\mathbf{1 2}$ \\
\hline
\end{tabular}

Table 1. Black bear trap nights in Grand Teton National Park.

Female and male collars were programmed to record positions every 190 and 90 minutes, respectively. Telonics CR2-A collar decouplers were programmed to release collars from all individuals on October 1, 2006. The SST units were also programmed for downloading communication every Tuesday and Thursday from $0800 \mathrm{hrs}-1200 \mathrm{hrs}$ MDT.

Generally, downloads occurred during weekly flights. From each week's data sets, a 24 hour period of locations was then chosen randomly for each bear, and all recorded positions were visited for detailed site analyses within a week's time of occupancy. Target sites were not visited when marked bears were nearby so as to not affect their movements.

\section{Site Visits}

Bear use of each site was determined by conducting searches within 15 meters of the locations. Each location was investigated for grazing, $\log$ rips, tree cambium tears, day beds, scats, digs, tree rubs, carcasses and several other feeding and non feeding activities (Appendix $1^{*}$ ). An established feeding site protocol developed by the IGBST (Mattson 1989, Mattson and Blasche 1990, Podruzny and Schwartz 2002) was followed. Detailed information included (1) physical site characteristics, (2) vegetation, and (3) black bear activity. Procedures included (1) a standard variableradius forest overstory inventory plot, (2) cover and frequency of bear foods from microplots, (3) a plant species list with cover, abundance, and phenology ratings, (4) standard site parameters, and (5) feeding and bedding activity analysis (Mattson and Blasche 1990). We used Hitchcock and Cronquist (1973) as the definitive flora, Pfister et al. (1977) and Steele et al. (1983) for standard climax habitat types, and the classifications of Despain (1986) for forest cover types. All bear scats at feed sites and scats encountered during travels among sites were 
collected. Black bear food habits will be estimated from feeding site analyses and from laboratory analysis of scats. Bear species identification will be determined using polymerase chain reaction amplification and mitrochondrial DNA determination following the procedures of Waits (1996). Evidence of various feeding activities is variably observable and persistent, and easily digestible food items can be under-documented in fecal analyses. By using both techniques, food items will be identified that one technique alone might miss. Collected scats will be air-dried and their volume measured by volumetric displacement. After softening by soaking in water, the scats will be washed through 2 screens (holes 0.125 and 0.0328 inches) to retain coarse and fine material. All items will be identified to species when possible and the percent volume for each item will be visually estimated (Mattson et al. 1991).

Forage items $(>5 \%)$ identified in bear scats will be collected at bear feeding sites and random locations. Samples will be oven-dried at $40^{\circ} \mathrm{C}$ for 48 hours and then stored in plastic bags in a freezer pending chemical analysis. If funding is available, dried samples will be analyzed for crude protein, dietary fiber, and ash (Pritchard and Robbins 1990). Root samples will also be analyzed for starch content. Because we did not know details of annual food habits prior to scat collection and analysis, we used previously published data (Barnes 1967, Graham 1978, Mealey 1980, Hammond 1983, Harting 1985, Mack 1988, Mattson et al. 1991, Holm 1998) to guide forage reference collections efforts the first year. In the following year, we will rely on results from scat analyses and published information. We anticipate that there will be approximately 12-15 major food items for the black bear.

\section{SOME PRELIMINARY RESUlTS}

Six female and 5 male black bears were trapped in 2005. Radio collars were deployed on 4 female and 3 male bears, although one male bear dropped its collar within a week of deployment (Table 2). Two females (22220 and 22212) had 2 cubs of the year each when captured. Collar downloading flights began on 21 June, after the first bear was collared, and continued weekly until 25 October. A total of nearly 2700 locations were gathered during this period (Table 2, Appendix $2 *$ ), about 150 of which were visited for detailed documentation of habitat, feed site, and behavioral attributes. Sites not visited will also eventually be analyzed through remote sensing techniques.

Two bears captured in 2005 had been captured previously. Bear 22046 was captured in July 2004 and fitted with a store-on-board GPS collar. She had been observed early in 2005 with a cub of the year, but was in estrus when caught in August, indicating her cub had died sometime previously. Bear 22212, a very old female, had been caught in the Tetons in August 2002 during an earlier black bear study led by the Wildlife Conservation Society, but was no longer wearing a radio collar when caught in 2005 . The remaining nine bears had not been captured before.

On a somewhat subjective, body indexing scale, all bears appeared to be in good physical condition. More objectively, fat measurements showed gradual increases in fat content throughout the summer, as would be expected; none of the bears had outlying measurements (Fig 2). Age of bears caught ranged from 1 to 20 years, with only the oldest bear showing signs of severely worn teeth.

\begin{tabular}{|c|c|c|c|c|c|c|c|c|}
\hline Capture & Bear & & & & & GPS & Habitat & \\
\hline Date & ID & Sex & Age & Collar & Location & Position & Plots & Comment \\
\hline $19 / 6 / 05$ & 22220 & F & 6 & Y & Kaulfman & 773 & 54 & 2 cubs of the year \\
\hline $02 / 7 / 05$ & 22221 & F & 1 & N & Kaulfman & & & \\
\hline $04 / 7 / 05$ & 22222 & M & 2 & N & Kaulfman & & & \\
\hline $16 / 7 / 05$ & 22223 & M & 2 & N & Kaulfman & & & Hunter killed in Idaho, 10/05 \\
\hline $18 / 7 / 05$ & 22224 & M & 2 & Y & Kaulfman & 560 & 12 & \\
\hline $02 / 8 / 05$ & 22046 & F & 5 & Y & JY North & 440 & 12 & in estrus when captured \\
\hline $06 / 8 / 05$ & 22225 & M & 5 & Y & Kaulfman & 78 & 4 & Shed collar $8 / 11 / 05$ \\
\hline $12 / 8 / 05$ & 22226 & F & 4 & Y & JY North & 362 & 16 & \\
\hline $15 / 8 / 05$ & 22227 & F & 2 & N & Jenny L. & & & 2 cubs of the year \\
\hline $21 / 9 / 05$ & 22212 & F & 20 & Y & JY North & 20 & 0 & \\
\hline $29 / 9 / 05$ & 22228 & M & 8 & Y & Kaulfman & 207 & 25 & \\
\hline \multicolumn{7}{|c|}{ Totals } \\
\hline
\end{tabular}

Table 2. Collar status, GPS positions, collection, and habitat plots documented for black bears, 2005

\footnotetext{
*Appendixes are available upon request. Contact UW-NPS through our website www.uwyo.edu/uwnps
} 
positions collected and plots documented as of October 14, 2005

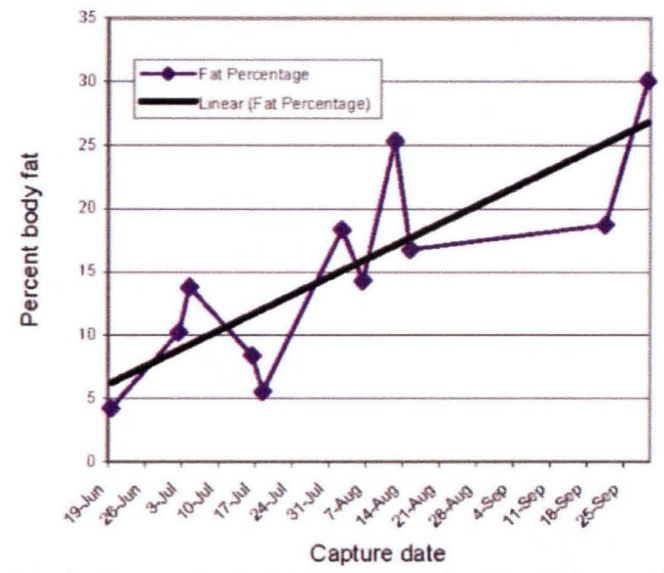

Fig. 2. Percent body fat of 11 individual black bears when captured.

As of the last flight on 25 October, all four collared females were denned in the Death Canyon area (Fig. 3). Bear 22228, an adult male, discovered 2 elk carcasses in mid to late October, and had not denned by this flight. Bear 22224, a subadult male, was northeast of the Gros Ventre Range's Green Mountain feeding on whitebark pine nuts in late October and had also not denned. Bear 22223, which was not collared, was harvested in Idaho by a hunter in October.

We documented bears using a wide variety of foods in 2005. Hawthorn (Crataegus douglasii) berries were an important food to three females in September and October (Fig. 4). An additional unmarked sow with 2 cubs of the year was also observed focusing on hawthorn berries during this time. Several of the females worked hawthorn thickets that were either along the Moose- Wilson road or in the general MooseWilson corridor area (Fig. 5). Hawthorn shrubs are not specific to this area but thrive in the southwestern part of the park. These preliminary data clearly illustrate the importance of this area and hawthorn to black bears.

Bear 22224, a two-year-old male, left the park and frequented a 4 mile stretch of the Fish Creek road to Teton Village corridor during July and August. This area shares many of the same excellent bear habitat features that occur in the southern end of the park, but has been somewhat of a mortality pit for park bears because of the many unsecured human food sources associated with residential development. In recent years, at least 3 park bears with no nuisance history in the park have been euthanized in this area by the Wyoming Game and Fish Department (WGFD). WGFD was

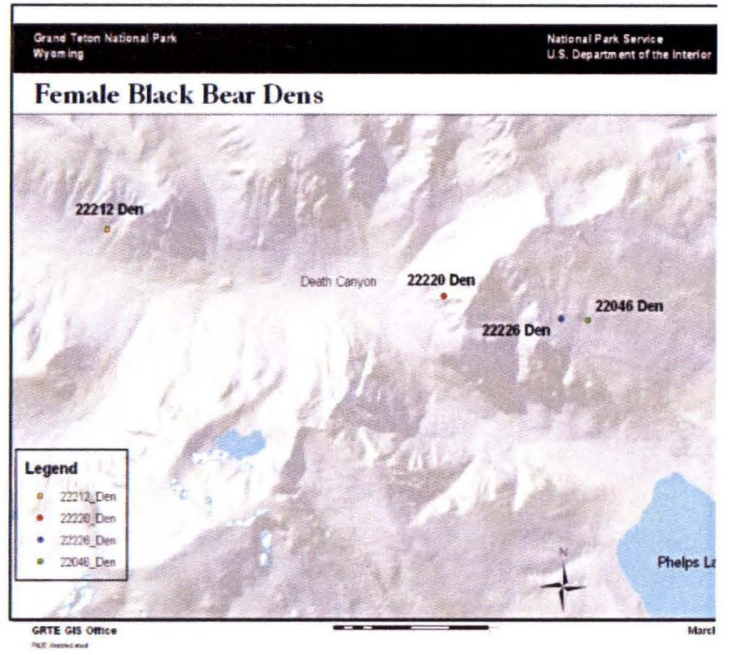

Figure 3. Den locations for 4 radio-marked female black bears.

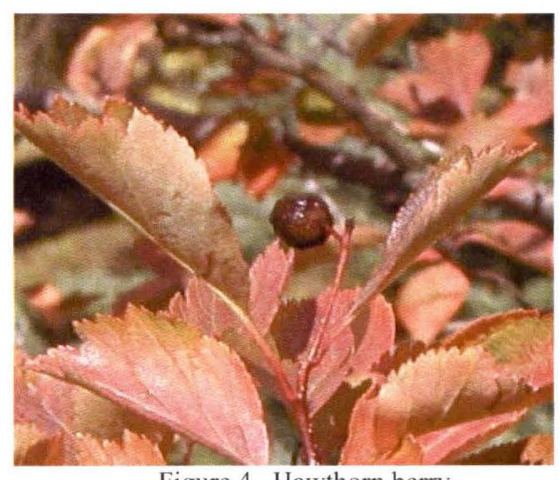

Figure 4. Hawthorn berry

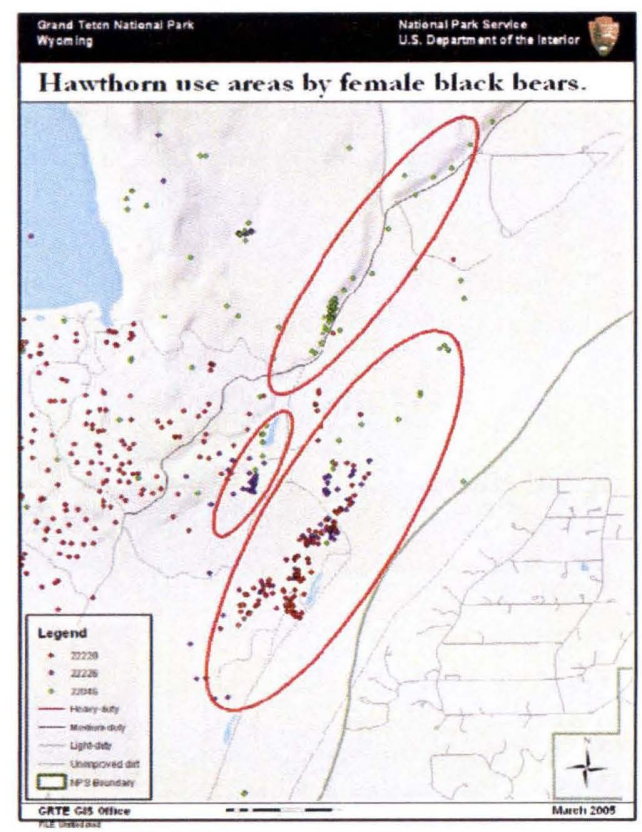

Fig. 5. Concentrated use of hawthorn by 3 black bears. 
actively pursuing at least one nuisance bear during the period 22224 was in the area in 2005, but he was never trapped. He made a long, northeast movement to the Gros Ventre range by September (see Appendix 2*).

\section{FUTURE DIRECTION}

The 2006 field season will focus on conducting detailed habitat and feeding site inventories at sites downloaded from the bears currently radio-instrumented, as soon as they emerge from dens, and collaring additional bears to increase sample size as funding permits. In addition, high priority will be given to establishing an additional habitat field crew to increase our capacity for site visits and inventories.

\section{$\uparrow \quad$ ACKNOWLEDGEMENTS}

This work was supported by grants from the Charles Engelhard Foundation, Earth Friends Wildlife Foundation, Greater Yellowstone Coordinating Committee, University of Wyoming/National Park Service Research Station, John and Karin McQuillan, and The Wildlife Society - Wyoming Chapter Memorial Bear Fund, Grand Teton National Park Foundation, and by Grand Teton National Park and the USGS Interagency Grizzly Bear Study Team. Leslie Mattson-Emerson was instrumental in securing many of the grants. Project collaborators included: Mark Haroldson, Craig Whitman, Shannon Podruzny, Karrie West, and Matt Newman - Interagency Grizzly Bear Study Team. Field assistants Chelsea Rector and Andrea Drayer provided critical daily support. GTNP biologists Sue Wolff, Sarah Dewey, and Kathy McFarland assisted with bear immobilizations. Mountain Air Research's Gary Lust piloted the downloading flights.

\section{Literature Cited}

Barnes, V.G. 1967. Activities of black bears in Yellowstone National Park. M.S. Thesis, Colorado State University, Fort Collins, Colorado, USA.

Despain, D.G. 1986. Habitat type and cover type as a base for grizzly bear mapping and evaluation. Pages 230-233 in G. Contreras and K. Evans, compilers. Proceedings-Grizzly Bear Habitat
Symposium. U.S. Forest Service General Technical Report INT-207.

Graham, D.C. 1978. Grizzly bear distribution, use of habitats, food habits, and habitat characterization in Pelican and Hayden valleys, Yellowstone National Park. M.S. Thesis, Montana State University, Bozeman, Montana, USA.

Hammond, F.M. 1983. Food habits of black bears in the Grey's River drainage, Wyoming. M.S. Thesis, University of Wyoming, Laramie, Wyoming, USA.

Harting, A.L. 1985. Relationships between activity patterns and foraging strategies of Yellowstone grizzly bears. M.S. Thesis, Montana State University, Bozeman, Montana, USA.

Hitchcock, C.L, and A. Cronquist, 1973. Flora of the Pacific Northwest, an illustrated manual. University of Washington Press, Seattle, Washington. 730 pp.

Holm, G.W. 1998. Interactions of sympatric black and grizzly bears in northwest Wyoming. M.S. Thesis, University of Wyoming, Laramie. 76pp.

Mack, J.A. 1988. Ecology of black bears on the Beartooth face, South-Central Montana. M.S. Thesis, Montana State University, Bozeman, Montana, USA.

Mattson, D. J. 1989. Interagency grizzly bears study feed site/habitat analysis. Memo.

Mattson, D. J., and L. Blasche. 1990. Field procedures for collecting data on grizzly bear feeding sites in the Yellowstone ecosystem. U.S. Department of the Interior, National Park Service, Interagency Grizzly Bear Study Team Report. 18 pp.

Mattson, D. J., B. M. Blanchard, and R. R. Knight. 1991. Food habits of Yellowstone grizzly bears, 1977-1987. Canadian Journal of Zoology 69:16191629.

\footnotetext{
*Appendixes are available upon request. Contact UW-NPS through our website www.uwyo.edu/uwnps
} 
Mealey, S. P. 1980. The natural food habits of grizzly bears in Yellowstone National Park. International Conference on Bear Research and Management 3:281-292.

Pfister, R. D., B. L. Kovalchik, S. F. Arno, and R. C. Presby. 1977. Forest habitat types of Montana. U.S. Forest Service General Technical Report INT-34.

Podruzny, S., and C.C. Schwartz. 2002. Habitat partitioning by grizzly and black bears in Yellowstone and Grand Teton National Parks. Pages 53-55 in C. C. Schwartz and M. A. Haroldson, editors. Yellowstone grizzly bear investigations: annual report of the Interagency Grizzly Bear Study Team, 2001. U.S. Geological Survey, Bozeman, Montana.

Pritchard, G.T., and C.T. Robbins. 1990. Digestive and metabolic efficiencies of grizzly and black bears. Canadian Journal of Zoology 68:1654-1661.

Pyare, S.,S. Cain, D. Moody, C. Schwartz, and J. Berger. 2004. Carnivore re-colonisation: reality, possibility and a non-equilibrium century for grizzly bears in the southern Yellowstone Ecosystem. Animal conservation 7:107.

Schwartz, C.C., M.A. Haroldson,, K.A. Gunther, and D. Moody. 2002. Current distribution of grizzly bears in the Greater Yellowstone ecosystem, 19902000. Ursus 13:203-213.

Steele, R., S.V. Cooper, D.M. Ondov, D.W. Roberts, and R.D. Pfister. 1983. Forest habitat types of eastern Idahowestern Wyoming. USDA Forest Service General Technical Report INT-144. 122pp.

Waits, L.P. 1996. A comprehensive molecular study of the evolution and genetic variation of bears. Ph.D. Thesis, University of Utah, Logan, Utah, USA. 